University of Nebraska - Lincoln

DigitalCommons@University of Nebraska - Lincoln

Faculty Publications of the Center on Children, Families, and the Law

Children, Families, and the Law, Center on

2020

\title{
Mandatory, Fast, and Fair: Case Outcomes and Procedural Justice in a Family Drug Court
}

Melanie Fessinger

Katherine Hazen

Jamie Bahm

Jennie Cole-Mossman

Roger Heideman

See next page for additional authors

Follow this and additional works at: https://digitalcommons.unl.edu/ccflfacpub

Part of the Administrative Law Commons, Courts Commons, Criminology and Criminal Justice Commons, Domestic and Intimate Partner Violence Commons, Family Law Commons, Family, Life Course, and Society Commons, Juvenile Law Commons, Law and Psychology Commons, Law Enforcement and Corrections Commons, Nonprofit Organizations Law Commons, Social Policy Commons, Social Welfare Commons, and the Social Welfare Law Commons

This Article is brought to you for free and open access by the Children, Families, and the Law, Center on at DigitalCommons@University of Nebraska - Lincoln. It has been accepted for inclusion in Faculty Publications of the Center on Children, Families, and the Law by an authorized administrator of DigitalCommons@University of Nebraska - Lincoln. 
Authors

Melanie Fessinger, Katherine Hazen, Jamie Bahm, Jennie Cole-Mossman, Roger Heideman, and Eve Brank 


\title{
Mandatory, Fast, and Fair: Case Outcomes and Procedural Justice in a Family Drug Court
}

\author{
Melanie Fessinger, ${ }^{1}$ Katherine Hazen, ${ }^{1}$ Jamie Bahm, ${ }^{2}$ Jennie Cole-Mossman, ${ }^{2}$ \\ Roger Heideman, ${ }^{3}$ and Eve Brank ${ }^{1}$
}

1. Center on Children, Families, and the Law and the Department of Psychology, University of Nebraska-Lincoln, 206 S. 13th Street, Suite 1000, Lincoln, Nebraska, USA

2. Center on Children, Families, and the Law, University of Nebraska-Lincoln, 206 S. 13th Street, Suite 1000, Lincoln, Nebraska, USA

3. Lancaster County Juvenile Court, 575 10th St., Lincoln, Nebraska, USA

\begin{abstract}
Objectives: Problem-solving courts are traditionally voluntary in nature to promote procedural justice and to advance therapeutic jurisprudence. The Family Treatment Drug Court (FTDC) in Lancaster County, Nebraska, is a mandatory dependency court for families with allegations of child abuse or neglect related to substance use. We conducted a program evaluation examining parents' case outcomes and perceptions of procedural justice to examine whether a mandatory problem-solving court could replicate the positive outcomes of problem-solving courts. Methods: We employed a quasiexperimental design that compared FTDC parents to traditional dependency court parents (control parents). We examined court records to gather court orders, compliance with court orders, case outcomes, and important case dates. We also conducted 263 surveys $(F T D C=232$; control $=31$ ) to understand parents' perceptions of procedural justice in the court process. Results: Overall, FTDC parents were more compliant with some court orders than control parents. Although FTDC and control parents did not have significantly different case outcomes, FTDC parents' cases closed significantly faster than control parents' cases. FTDC parents also had higher perceptions of procedural justice than control parents. Mediation analyses indicated that FTDC parents believed the court process was more fair and therefore participated more consistently in court-ordered services and therefore reunified more often than control parents. Conclusions: Mandatory problem-solving courts can serve parents through the same mechanisms as voluntary problem-solving courts. More research is necessary to examine which specific elements of problem-solving courts, aside from the voluntary nature, are essential to maintain their effectiveness.
\end{abstract}


Keywords: dependency courts, family drug courts, mandatory treatment, problem-solving courts, procedural justice, substance use, therapeutic jurisprudence

\section{Introduction}

The traditional punitive court model is ill-equipped to deal with some of the complex social and psychological issues that bring individuals into the legal system. Scholars have argued that the traditional punitive court model addresses symptoms rather than dealing with the underlying problems that bring individuals before courts (Winick 2013). Accordingly, some courts across the country have shifted their focus away from punishment and toward rehabilitation in order to better serve the individuals who come on their dockets and to reduce rates of recidivism (Winick 2013). These rehabilitation-focused courts, known as "problem-solving courts," attempt to reach deeper than traditional courts by resolving both the immediate dispute before them as well as the underlying issues that caused it (Winick 2003).

Problem-solving courts are an application of therapeutic jurisprudence (Kaiser and Holtfreter 2016; Wiener et al. 2010; Winick 2003, 2013). Therapeutic jurisprudence is an interdisciplinary approach to legal reform that seeks to identify ways of improving the well-being of those involved in the legal system (Kaiser and Holtfreter 2016; Wiener et al. 2010; Winick 2003). It acknowledges that legal actors and the law itself are therapeutic, or anti-therapeutic, forces that affect those who interact with the legal system (Winick 2003). Judges adopting the principles of therapeutic jurisprudence act as therapeutic agents by assessing the social or psychological dysfunction that brought individuals before the court, encouraging their compliance with services that will address that dysfunction, and monitoring their behavior closely (Gatowski et al. 2013; MacKenzie 2016).

Therapeutic jurisprudence offers legal actors several tools to work successfully toward rehabilitation. One such tool is procedural justice, which refers to individuals' perceptions of formal decision-making processes as satisfactory and fair (Tyler 1989). According to procedural justice theory, individuals perceive a decision-making process as more fair if they are allowed to express their preferences about the process and the outcome (commonly referred to as "voice"), if they perceive that the decision-maker has good intentions toward them (commonly referred to as "trust"), if they perceive that the decision-making process is the same for them as it would be for others in a similar situation (commonly referred to as "neutrality"), and if they feel they are treated with respect and dignity (commonly referred to as "respect") (Lind et al. 1997). Procedural justice posits that individuals who perceive a decision-making process as more fair are more likely to cooperate and comply with the decision (e.g., court orders, sanctions) than those who perceive it as less fair (Lind et al. 1997; Tyler and Huo 2002) because they perceive the decision-maker as more legitimate (Bradford 2014; Gerber et al. 2018).

Scholars have proposed that problem-solving courts achieve positive case outcomes at least to some extent because participants perceive the court process as more fair than those in traditional courts (Kaiser and Holtfreter 2016; Roman et al. 2011; Wales et al. 2010; Wiener et al. 2010). Moreover, they have proposed that therapeutic jurisprudence fosters perceptions of fairness and legitimacy in the court process which ultimately lead to their 
cooperation and compliance with the court (Kaiser and Holtfreter 2016). Studies examining the influence of problem-solving courts have found support for these proposals by finding that procedural justice mediates the relationship between participation in problem-solving courts and positive case outcomes (Frazer 2006; Gottfredson et al. 2007; Gover et al. 2007; McIvor 2009; Poythress et al. 2002; Roman et al. 2011). Therefore, there is some evidence to support the theory that problem-solving courts achieve more positive outcomes (such as abstinence from substance use, improved parenting, employment, dismissal of criminal charges) than traditional courts because therapeutic jurisprudence provides court-involved individuals with more procedural justice, which leads to greater cooperation and compliance. In this paper, we examined whether the mechanisms of therapeutic jurisprudence and procedural justice would also lead to positive case outcomes in a mandatory problemsolving court.

\section{Voluntary versus mandatory participation}

One of the primary ways in which problem-solving courts implement procedural justice is by allowing individuals the choice to voluntarily proceed on the alternative court process or to remain on the traditional court process (Wiener et al. 2010). Those who choose to participate in the alternative process first admit to the allegations against them and then agree to resolve the case through the alternative court process (Redlich 2010). Individuals' decision to participate in the alternative court process is their first exercise of voice in the decision-making process. This exercise of voice should increase individuals' perceptions of fairness and legitimacy in the court process which encourages their cooperation and compliance with court orders (Winick 2003). Accordingly, most of the literature on problemsolving courts has examined courts in which the participants voluntarily proceed on the problem-solving court process after consultation with their defense attorney (Frazer 2006; Gottfredson et al. 2007; Gover et al. 2007; Wiener and Brank 2010). In fact, Winick and Wexler (2002) have suggested that judges "should not attempt to pressure offenders to accept diversion into drug treatment court, but should remind them that the choice is entirely up to them" (p. 483). This prescription is consistent with the ideals of procedural justice, in that mandating participation in a problem-solving court removes the individuals' voice in the decision-making process and therefore may detract from their willingness to comply.

Despite the focus in the literature on allowing individuals the choice to voluntarily proceed through a problem-solving court, to our knowledge, there have been no studies examining whether voluntary participation is a necessary component of effective problemsolving courts. Moreover, voluntary participation is not required to adopt the ideals of therapeutic jurisprudence in a court process. In demonstrating this, judges have found subtle ways of using therapeutic jurisprudential approaches (e.g., sending letters to court participants summarizing their next steps; providing resources to aid court participants in completing their sentences) without court participants even being aware they are doing so (King 2008; Spencer 2012). Rather than being a precondition, voluntary participation is used to further procedural justice and to mitigate due process concerns. Therefore, in order to argue that voluntary participation is required to promote the positive effects of therapeutic jurisprudence, the relationship between procedural justice and positive case outcomes should be tested in a mandatory context. 
There has been extensive scholarship examining whether voluntary participation in rehabilitative treatment itself is necessary to promote positive outcomes. This literature can shed some light on whether voluntary participation in problem-solving courts is necessary for promoting rehabilitation. Contrary to the aforementioned concerns, this research suggests that mandating participation in rehabilitative treatment may not interfere with individuals' cooperation and compliance. Some scholars have argued that external motivations, such as legal pressure, may be necessary to motivate individuals to enter treatment and to remain in treatment once there (Looney and Metcalf 1974; Maddux 1988). In support of this argument, several studies have found that legal pressure provides an effective external motivation for individuals to enter, remain in, and complete treatment (Berkowitz et al. 1996; Copeland and Maxwell 2007; Farabee et al. 1998; Perron and Bright 2008; Rempel and Destefano 2001). For example, Hiller et al. (1998) examined 18 long-term residential substance use treatment programs and 2,605 individuals and found that those who were under moderate or high legal pressure (on probation or parole, monitored urinalysis tests, and/or court-ordered to participate) were more likely to remain in treatment for 90 days or longer than those under low legal pressure (no legal system involvement, no monitoring of urinalysis tests, and not court-ordered to participate). In fact, their results also showed that legal pressure was the strongest predictor of treatment retention. These findings, and others like them, support the widespread and increasing use of mandatory rehabilitative treatment (Klag et al. 2005).

Moreover, individuals who are mandated to participate in rehabilitative treatment may not even perceive their participation as involuntary (Poythress et al. 2002; Wild et al. 1998). For example, Wild et al. (1998) found that $35 \%$ of individuals legally mandated and $61 \%$ of individuals otherwise-mandated to participate in rehabilitative treatment perceived that they were under no coercion to enter treatment. These individuals reported that they had more influence than anyone else in deciding to attend treatment, that it was their idea to attend treatment, and that they were free to do what they wanted in terms of attending treatment. These findings suggest that individuals who are mandated to participate in rehabilitative treatment may not perceive it any differently than those who voluntarily participate, which is consistent with several studies that have found mandated and voluntary treatment yield similar treatment and legal outcomes (e.g., Brecht et al. 1993; Prendergast et al. 2002).

It is important to note, however, that mandatory treatment is not without critics and the research has not consistently demonstrated these positive or neutral effects. The criticisms come in many different forms, including arguments that personal autonomy is important for individuals to be motivated to engage in treatment (e.g., Wild et al. 1998), that mandatory interventions do not account for the wide variation in individuals' needs (e.g., Klag et al. 2005), and that mandating treatment infringes on individuals' civil liberties (e.g., Rosenthal 1988). Additionally, some studies have suggested that mandated treatment has worse outcomes than voluntary treatment. For example, Howard and McCaughrin (1996) found that treatment providers who mostly dealt with court-ordered individuals reported higher rates of treatment failure than those who mostly dealt with voluntary individuals.

Several decades of research on mandatory rehabilitative treatment have yielded an inconsistent pattern of results. Although the literature is inconclusive, many studies suggest 
that voluntary participation may not be necessary to encourage individuals' cooperation and compliance with rehabilitative treatment. In fact, the most recent guide on the principles of effective treatment by the National Institute on Drug Abuse explicitly states that "treatment does not need to be voluntary to be effective" (2018, p. 6). Importantly, however, rehabilitative treatment is only one component of problem-solving courts. Research has yet to examine the effects of mandating participation in a problem-solving court as $a$ whole. Therefore, in this paper, we address this gap in the literature by presenting an example of a mandatory family drug court that replicates the positive case outcomes found in previous research on problem-solving courts.

\section{Family drug courts}

Substance use is a pervasive problem in dependency court cases. Approximately 60 to $80 \%$ of child abuse and neglect cases involve substance use by a parent (Young et al. 2007). Parental substance use puts children at risk for maltreatment because parents' focus on obtaining and using drugs makes it difficult for them to meet their children's emotional and physical needs (Child Welfare Information Gateway 2014; United States General Accounting Office 1998). Their children are more likely to be placed in foster care, to remain in out-of-home care for longer periods of time, and to experience severe and chronic neglect (Barth et al. 2006; United States Department of Health and Human Services 1999).

Family drug courts are specialized problem-solving court tracks within dependency court systems that work toward rehabilitating parents with allegations of child abuse or neglect related to substance use (Marlowe and Carey 2012). Family drug courts implement the principles of therapeutic jurisprudence by encouraging parents' engagement in substance use treatment, coordinating parents' treatment plan with child protective services, and monitoring their progress closely (Marlowe and Carey 2012). Family drug courts monitor parents' progress by utilizing random drug testing, promoting interagency collaboration, and holding frequent court hearings (Worcel et al. 2008). The ultimate goal of family drug courts is for parents to successfully complete substance use treatment, to reunify with their children, and to prevent recidivism. As of 2017, 495 family drug courts were operating across the country (Breitenbucher et al. 2018).

Family drug courts are more successful than their traditional counterparts in both treatment and case outcomes. Family drug court parents are more likely than traditional dependency court parents to enroll in substance use treatment, enter treatment sooner, attend more treatment sessions, remain in treatment longer, and complete treatment (Ashford 2004; Boles et al. 2007; Carey et al. 2010; Green et al. 2007, 2009; Marlowe and Carey 2012; Oliveros and Kaufman 2011; Worcel et al. 2008). Family drug court parents are also more likely than traditional dependency court parents to be reunified with their children and to reunify more quickly (Ashford 2004; Boles et al. 2007; Carey et al. 2010; Green et al. 2007, 2009; Marlowe and Carey 2012; Worcel et al. 2008). However, family drug courts can vary in how they implement the core model into practice, which has led scholars to call for research on different variations to determine which aspects are most important to maintain (Green et al. 2009). Previous research has only examined family drugs courts where parents voluntarily opt on the alternative track (e.g., Ashford 2004; Bruns et al. 2012; Green et al. 
2009) and therefore does not demonstrate whether voluntary participation is one of those aspects.

\section{Present evaluation}

We conducted the present evaluation of the Lancaster County Family Treatment Drug Court (FTDC) to examine whether a mandatory family drug court could still promote participants' perceptions of procedural justice and ultimately lead to positive case outcomes. The mandatory nature of the FTDC raised concerns about whether it could still effectively achieve its goals of engaging parents to participate in treatment and to reunify with their children. As discussed in the preceding sections, procedural justice would suggest that mandating participation in the alternative court process deprives parents of voice in the decision-making process and therefore may detract from their willingness to cooperate and comply with court orders. However, many studies have also found mandatory substance use treatment can have positive effects. Therefore, the mandatory nature of the FTDC may not detract from (and may even enhance) the goal of getting parents into substance use treatment and reunifying the families. Although the present evaluation does not provide a direct comparison between voluntary and mandatory participation in a problemsolving court, the results provide one example where mandatory participation in a problemsolving court replicates the positive outcomes found with other problem-solving courts.

We conducted a quasi-experimental program evaluation by collecting data from parents assigned to the FTDC and parents in the traditional dependency court (hereinafter "control parents").We discuss the development of the control group in the section that follows. We collected data by (1) reviewing court records and (2) conducting surveys. We examined differences in compliance with court orders, case outcomes, timing to case outcomes, and perceptions of procedural justice. We also examined how parents' perceptions of procedural justice were related to the other key variables.

We developed several hypotheses. First, we expected that FTDC parents would have more consistent compliance with court orders because of their regular and frequent court contact. Second, we expected that FTDC cases would progress through the court process faster because parents would be more compliant with court orders. Third, despite the mandatory nature of the FTDC, we expected that FTDC parents would have higher perceptions of procedural justice in the court process than control parents because of their additional opportunities for voice (i.e., monthly family team meetings). Finally, we expected a serial mediation between court group and case outcomes through perceptions of procedural justice and compliance with court orders, such that FTDC parents' increased perceptions of procedural justice would result in more compliance with court-ordered services than control parents, which would result in more reunifications, faster reunifications, and faster case closures.

\section{Description of the program}

The Lancaster County Family Treatment Drug Court (FTDC) is a specialized problemsolving dependency court that began operating in 2014. It adheres to most of the typical components of family drug courts, including close monitoring, case management, regular 
urinalysis, active judicial leadership, and a multidisciplinary team (Bruns et al. 2012; Green et al. 2009; Worcel et al. 2008). The major difference between the FTDC and the typical family drug court model is that parents were ordered to participate in FTDC as part of the rehabilitation plan prescribed at their dispositional hearing. We describe major components of the FTDC and how that differed from the control group in the sections that follow and in Table 1.

Table 1. Key differences between Family Treatment Drug Court (FTDC) cases and traditional dependency court (control) cases

\begin{tabular}{lll}
\hline Variable & FTDC & Control \\
\hline Main issue in case & Substance use & $\begin{array}{c}\text { Various (e.g., mental illness, } \\
\text { homelessness) }\end{array}$ \\
Caseworker & $\begin{array}{c}\text { Formal review hearings every 3 months, } \\
\text { informal family team meetings } \\
\text { Fonthly }\end{array}$ & $\begin{array}{c}\text { Formal review hearings every 3 to 6 } \\
\text { months }\end{array}$ \\
& $\begin{array}{l}\text { Families work with specially trained } \\
\text { caseworkers solely dedicated to } \\
\text { Specialized services }\end{array}$ & - \\
& $\begin{array}{l}\text { Parents participate in specialized } \\
\text { services including substance use } \\
\text { evaluations, co-occurring evaluations, } \\
\text { and substance use treatment }\end{array}$ & - \\
\hline
\end{tabular}

\section{Assignment}

FTDC assignment

FTDC families were automatically assigned to the FTDC judge's docket when their initial child abuse or neglect petition included allegations of substance use. These cases included parents whose children tested positive for drugs and parents who used or possessed drugs in the presence of or while caring for their children. Parents could also be transferred to the FTDC if substance use was revealed to be a major issue later in their case. All eligible cases were placed on or transferred to the FTDC docket, with the exception of parents who had another dependency court case in front of another judge.

\section{Control assignment}

Control families were those with a case in front of the same FTDC judge but who were not eligible to be transferred onto the alternative track. Beginning in 2016, we worked with court administrative staff to identify child abuse and neglect cases assigned to the same judge who were not eligible for the FTDC. The court administrative staff identified the control families by indicating on the weekly court calendar which child abuse or neglect hearings were not FTDC families. Therefore, families were eligible for the control group if they had a dependency court case on the FTDC judge's docket and did not have substance use as a major issue identified in their case. We identified a total of 31 control families, which accounted for $14.55 \%$ of all eligible cases. We were unable to identify all eligible cases because we began identifying them 2 years after the evaluation began and because of the convenience sampling approach. 


\section{Court process}

\section{FTDC court process}

FTDC families followed a court process that was distinguishable from the traditional dependency court process in several respects. The court process diverged from the traditional dependency court process for FTDC families following their dispositional hearing. After the dispositional hearing where parents were ordered to participate in the FTDC, FTDC families appeared in court every 3 months for formal review hearings and monthly for family team meetings. Formal review hearings were on the record, presided over by the judge, and resulted in formal court orders. They were structured hearings to assess the parents' progress toward ameliorating the cause of adjudication, to adjust the rehabilitation plan as needed, and to establish a record of case progression. Family team meetings, which were the defining characteristic of the FTDC, were informal and provided the parties the opportunity to share updates, have group discussions, reach agreements to change the rehabilitation plan, and resolve barriers to rehabilitation. All relevant parties (e.g., parents, attorneys, caseworkers, service providers) could attend the family team meetings and have an open discussion about the parents' progress, successes, and barriers since the last reporting period. The family team meetings began with a parent self-reporting on their progress, sharing issues they would like the team to know about their children, and identifying topics they would like to discuss in the meeting. The caseworker facilitated the family team meetings but encouraged parents and other parties to actively participate in the discussion. The judge participated in the family team meetings for the last few minutes to directly ask the parents to report on their progress, to provide praise or encouragement where appropriate, and to remind the parents that the ultimate goal is to have the family safely reunify.

In addition to more frequent court attendance, FTDC families also had access to specialized professionals and services. First, FTDC families worked with a caseworker from a team solely dedicated to working with families on the track. These caseworkers were trained on the unique issues associated with substance use and the services that were available to the families. Second, FTDC parents participated in specialized services, including substance use evaluations, co-occurring evaluations, substance use treatment, and random urinalysis testing. Depending on the case facts and evaluation recommendations, they could also receive services not specific to substance use, such as parenting classes or domestic violence interventions.

\section{Control court process}

Control families proceeded through the traditional dependency court process. After the dispositional hearing, control families participated in formal review hearings (described above) every 3 to 6 months. Formal hearings were their only dependency court attendance. Control families also participated in family team meetings; however, these were distinguishable from the FTDC family team meetings because they took place out of court and did not involve the judge. Their family team meetings involved their caseworker and attorney at a neutral location (e.g., family home, office) to discuss case progress. 


\section{Part 1: Court records}

\section{Sample}

The sample included $293(82.77 \%)$ FTDC parents and $61(17.23 \%)$ control parents $(N=354$ parents) involved in the dependency court. This total included 310 adjudicated parents $($ FTDC $=261$, control $=49)$ and 44 nonadjudicated parents $(F T D C=32$, control $=12)$ who had some involvement in the case. Most parents were mothers $($ FTDC $=154$, control $=31$ ); fewer were fathers $(\mathrm{FTDC}=107$, control $=18)$. On average, each parent had $2.10(S D=1.23)$ children who were $4.48(S D=3.78)$ years old. There were a total of 378 children. The majority of children were White (59.30\%), Native American (11.90\%), or Black/African American $(11.30 \%)$ (see Table 2 for full description of the families in each group).

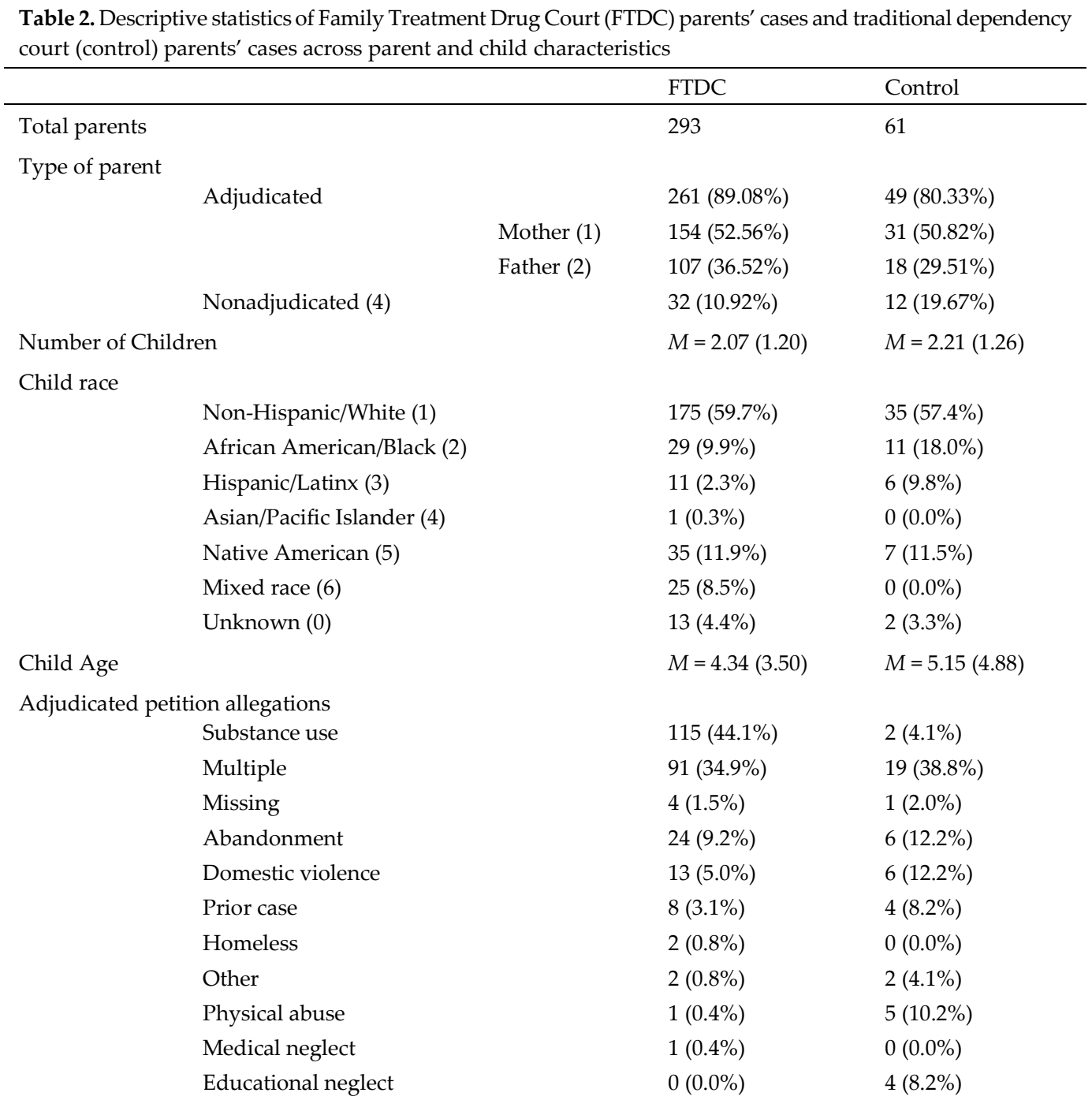

Parentheticals indicate the code used for category. 
Quasi-experimental designs often rely on propensity score matching to replicate the assumptions of random assignment in a true experimental design (West et al. 2014a, 2014b). The causal risk of quasi-experimental design is the variance introduced at baseline by history, selection, and assignment. Propensity score matching corrects for the bias in the causal effect of the nonrandom assignment by equating the treatment group and the control group at baseline (West et al. 2014b). For propensity score matching to be appropriate, baseline measures must be statistically and theoretically related to the group membership and the outcome measures (West et al. 2014a, 2014b). Due to the quasi-experimental design used in the present evaluation, we examined the statistical relationship between the court group and parent gender, number of children, mean age of children, child race, native American tribal status, previous child dependency case with the same children, allegations of failure to protect the child in the petition, allegations of substance use in the petition, average service participation, procedural justice scores, reunification, days from petition to reunification, case closure, and days from petition to case closure. Due to the administrative nature of our data collection and assignment procedures, we did not have measures of motivation throughout the evaluation and were unable to control for its influence (see Bruns et al. 2012). The only baseline parent, child, or case characteristic significantly correlated with court group was allegations of substance use in the petition $(r=.46, p<.001)$, which we would expect to be significantly and strongly associated with court group as it is the primary factor in assignment. Additionally, procedural justice scores, a dependent variable, was significantly correlated with court group $(r=.19, p=.02)$. All other correlations with court group were weak $\left(r^{\prime} \mathrm{s}<.13\right)$ and nonsignificant $\left(p^{\prime} \mathrm{s}>.05\right)$ (see Table 3 for the descriptive statistics and correlation matrix). Therefore, propensity score matching is not indicated by the data and we can proceed with the analyses assuming variance between the groups is due to the history of substance use and the differing court procedures.

\section{Method}

Research assistants accessed Nebraska's online case management system to collect information about each identified case. They read the legal and social files of each family to record parents' court orders, participation in evaluations and services, important case dates, and case outcomes. The main dependent variables of interest were parents' compliance with court orders, case outcomes, and time to case outcomes.

\section{Compliance with court orders}

Research assistants reviewed parents' court orders for the entire length of their case. They coded whether the court ordered parents to participate $(0=$ not ordered, $1=$ ordered $)$ in several evaluations and services. We compiled a complete list of potential evaluations and services by working with the judge and caseworkers. The evaluations included a substance abuse evaluation, co-occurring evaluation, psychological evaluation, neuropsychological evaluation, medication-management evaluation, parenting assessment, and child-parent dyadic assessment. The services included visitation, individual therapy, family therapy, child-parent psychotherapy, parenting classes, domestic violence classes, and peer support. 
FESSINGER ET AL., JOURNAL OF EXPERIMENTAL CRIMINOLOGY 16 (2020)

\begin{tabular}{|c|c|c|c|c|c|c|c|c|c|c|c|c|c|c|c|c|c|c|}
\hline & $N$ & $\begin{array}{c}M \\
(S D)\end{array}$ & Frequency & 1 & 2 & 3 & 4 & 5 & 6 & 7 & 8 & 9 & 10 & 11 & 12 & 13 & 14 & 15 \\
\hline 1. Court group & 354 & & $\begin{array}{l}\text { FTDC }(1)=293 \\
\text { Control }(0)=61\end{array}$ & - & & & & & & & & & & & & & & \\
\hline 2. Parent gender & 354 & & & -.08 & - & & & & & & & & & & & & & \\
\hline 3. Child age & 354 & $\begin{array}{c}4.48 \\
(3.78)\end{array}$ & & -.08 & .03 & - & & & & & & & & & & & & \\
\hline 4. Child race & 350 & & & .06 & $.12^{*}$ & -.04 & - & & & & & & & & & & & \\
\hline $\begin{array}{l}\text { 5. Number of } \\
\text { children }\end{array}$ & 351 & $\begin{array}{c}2.10 \\
(1.23)\end{array}$ & & -.04 & $.17^{* *}$ & $.26^{* * *}$ & .05 & - & & & & & & & & & & \\
\hline 6. Tribal status & 313 & & $\begin{array}{l}\text { Yes }(1)=28 \\
\text { No }(0)=285\end{array}$ & .04 & .01 & -.06 & $.45^{* * *}$ & .05 & - & & & & & & & & & \\
\hline 7. Previous case & 306 & & $\begin{array}{l}\text { Yes }(1)=20 \\
\text { No }(0)=25\end{array}$ & -.13 & .13 & -.06 & .17 & .16 & $.30^{*}$ & - & & & & & & & & \\
\hline 8. Failure to protect & 306 & & $\begin{array}{l}\text { Yes }(1)=34 \\
\text { No }(0)=272\end{array}$ & -.02 & $-.18^{* *}$ & .02 & .01 & .05 & -.00 & $-.39^{* *}$ & - & & & & & & & \\
\hline 9. Substance use & 306 & & $\begin{array}{l}\text { Yes }(1)=213 \\
\text { No }(0)=93\end{array}$ & $.46^{* * *}$ & $-.35^{* * *}$ & -.05 & -.05 & -.06 & -.04 & -.18 & -.02 & - & & & & & & \\
\hline $\begin{array}{l}\text { 10. Procedural } \\
\text { justice score }\end{array}$ & 159 & $\begin{array}{c}4.24 \\
(0.85)\end{array}$ & & $.19^{*}$ & -.06 & -.09 & -.01 & .01 & -.00 & -.00 & -.06 & .09 & - & & & & & \\
\hline $\begin{array}{l}\text { 11. Average service } \\
\text { participation }\end{array}$ & 305 & $\begin{array}{c}1.60 \\
(1.09)\end{array}$ & & .07 & $.16^{* *}$ & -.09 & -.05 & .01 & -.05 & .14 & .06 & $.25^{* * *}$ & $.29^{* * *}$ & - & & & & \\
\hline 12. Reunification & 354 & & $\begin{array}{l}\text { Yes }(1)=118 \\
\text { No }(0)=231\end{array}$ & $.20^{* * *}$ & .09 & -.03 & -.01 & .05 & $-.14^{*}$ & -.17 & $-.12^{*}$ & $.15^{* *}$ & -.01 & -.10 & - & & & \\
\hline $\begin{array}{l}\text { 13. Days from petition } \\
\text { to reunification }\end{array}$ & 96 & $\begin{array}{c}272.53 \\
(182.06)\end{array}$ & & -.03 & -.10 & $.22^{*}$ & -.02 & -.00 & -.10 & .17 & -.03 & .01 & -.02 & $-.30^{* *}$ & .04 & - & & \\
\hline 14. Case closure & 354 & & $\begin{array}{l}\text { Yes }(1)=187 \\
\text { No }(0)=125\end{array}$ & .04 & $-.75^{* *}$ & -.01 & $-.16^{* *}$ & -.09 & .05 & -.16 & .04 & .08 & .03 & $-.23^{* *}$ & -.05 & .10 & - & \\
\hline $\begin{array}{l}\text { 15. Days from petition } \\
\text { to case closure }\end{array}$ & 186 & $\begin{array}{c}478.63 \\
(254.93) \\
\end{array}$ & & $-.22^{* *}$ & $-.28^{* *}$ & .07 & $.15^{*}$ & .05 & .02 & .10 & $.19^{*}$ & -.00 & -.15 & $-.26^{* *}$ & -.02 & $.84^{* *}$ & - & - \\
\hline
\end{tabular}

${ }^{*} p<.05,{ }^{* *} p<.01,{ }^{* * *} p<.001$ 
The research assistants also reviewed parents' case plans for the entire length of their case. If the court ordered parents to participate in an evaluation, they coded whether parents ever completed the evaluation $(0=$ not completed, $1=$ completed $)$. If the court ordered parents to participate in a service, they coded whether parents participated in that service in the most recent six-month reporting period $(0=$ did not participate, $1=$ participated inconsistently, 2 = participated consistently, 3 = completed participation). Participation was considered inconsistent when parents missed multiple meetings and did not provide a legitimate justification for the absence as reported to the court by their caseworker. An example of inconsistent participation would be if the parent scheduled regular therapy and did not attend four of the last six appointments with no justification. Participation was considered consistent when parents missed no meetings or a very small number of meetings with an identified reason. An example of consistent participation would be if the parent scheduled regular therapy and attended six of the last six appointments, or five of the last six appointments and appropriately canceled the one appointment beforehand because the parent was sick. We created composite variables for parents' average evaluation participation (range of potential scores $=0-1$ ) and parents' average service participation (range of potential scores $=0-3$ ) by averaging parents' participation across the evaluations and services.

\section{Case outcomes}

Research assistants also coded for several possible case outcomes that could have occurred in parents' cases $(0=$ did not occur, $1=$ did occur), including reunification, case closure, and successful case closure. Reunification occurred when the court returned physical custody of the child to the parent $(0=$ not reunified, $1=$ reunified $)$. Following reunification, the case remained open until the court was satisfied that the child was safe and that parent had corrected the adjudicated issues. Case closure occurred when the court terminated its jurisdiction over the family. We categorized case closure by whether it was successful $(0=$ not successful, 1 = successful). Successful case closure occurred when the court terminated its jurisdiction over the child following reunification. Unsuccessful case closure occurred when the court terminated its jurisdiction over the children following a voluntary relinquishment or involuntary termination of parental rights. Although these might be positive outcomes for the children depending on the facts of the case, we conducted this evaluation at the parent-level and thus treated success in terms of retention of parental rights. Additionally, although a primary goal of problem-solving courts is to reduce recidivism, this ultimate outcome was not available in these court records and therefore was not included in our analyses.

Time to case outcomes

Research assistants also coded parents' case progression by recording the dates on which important events occurred. Time to case outcomes is an important variable in this context because meeting milestones earlier suggests faster compliance with court orders and less time that the children are awaiting permanency. The milestones they coded for included the date of removal, petition, and the case outcomes mentioned in the preceding section. Removal occurred when the State removed the children from the parents' physical custody. Petition occurred when the State submitted its initial court filing that contained 
allegations of child abuse or neglect against the parent. We calculated the time to case outcomes by subtracting the number of days between each pair of target events.

\section{Results}

Compliance with court orders

The court ordered FTDC parents and control parents to participate in several evaluations and services. On average, FTDC families had 17.96 court orders $(S D=4.63)$ and control families had 14.45 court orders $(S D=3.94)$. A one-way between-group analysis of variance (ANOVA) revealed that FTDC families had significantly more court orders than control families, $F(1,179)=15.48, p<.01, \eta^{2}=.08$; this difference likely accounted for the additional court orders to participate in substance use evaluations and services and in-court family team meetings.

Overall, both FTDC parents and control parents were moderately compliant with court orders. A one-way between-group ANOVA revealed there was a significant mean difference between court group on average evaluation participation scores, $F(1,192)=4.07, p=.045$, $\eta^{2}=.02$, showing that FTDC parents $(M=0.61, S D=0.58)$ complied more consistently with court-ordered evaluations than control parents $(M=0.44, S D=0.47)$. However, there was no significant mean difference between court group on average service participation scores, $F(1,304)=1.27, p=.26$, showing that FTDC parents $(M=1.63, S D=1.07)$ and control parents $(M=1.44, S D=1.17)$ had similar compliance with court-ordered services.

\section{Case outcomes}

One hundred and eighteen parents $(F T D C=102$, control $=16)$ reunified with their children. Twenty-three parents (FTDC $=15$, control $=8$ ) who reunified with their children were nonadjudicated. There was no significant proportional difference in reunification between FTDC parents (34.81\%) and control parents $(26.23 \%), \chi^{2}(1)=1.00, p=.32$.

Three hundred and ten adjudicated parents $($ FTDC $=261$, control $=49)$ were formally involved in the court process and therefore could have a formal case closure. The court terminated its jurisdiction over 187 parents' cases (FTDC $=159$, control $=28)$. There was no significant proportional difference in case closure between FTDC parents $(71.65 \%)$ and control parents $(80.33 \%), \chi^{2}(1)=0.25, p=.62$.

Case closure was divided amongst those that were successful and those that were unsuccessful. Seventy-eight parents' cases $(\mathrm{FTDC}=69$, control $=9$ ) closed successfully following reunification. One hundred and nine parents' cases $($ FTDC $=90$, control $=19)$ closed unsuccessfully after a voluntary relinquishment or involuntary termination of parental rights. There was no significant proportional difference in successful case closures between FTDC $(32.14 \%)$ and control parents $(43.40 \%), \chi^{2}(1)=1.24, p=.27$.

\section{Time to case outcomes}

The average number of days between parents' important case milestones is presented in Table 4. A one-way between-group ANOVA revealed there was no significant difference in time from petition to reunification between FTDC parents $(M=270.51, S D=185.40)$ and control parents $(M=288.18, S D=160.79), F(1,94)=0.09, p=.764, \eta^{2}=.001$. Instead, case 
closure drove all significant effects between FTDC and control parents in time to case outcomes. FTDC parents' cases closed in significantly fewer days than control parents, $F(1,184)$ $=9.48, p=.002, \eta^{2}=.05$. The average number of days from petition to case closure was 454.94 $(S D=228.47)$ for FTDC parents and $612.29(S D=346.40)$ for control parents.

Table 4. Average number of days (SD) between important court hearings and case outcomes for Family Treatment Drug Court (FTDC) parents and traditional dependency court (control) parents

\begin{tabular}{|c|c|c|c|c|c|c|c|}
\hline $\begin{array}{l}\text { Hearing/ } \\
\text { outcome }\end{array}$ & & Petition & Removal & $\begin{array}{c}\text { Reunifi } \\
\text { cation }\end{array}$ & $\begin{array}{l}\text { Voluntary } \\
\text { relinquish- } \\
\text { ment }\end{array}$ & TPR & $\begin{array}{l}\text { Case } \\
\text { closure }\end{array}$ \\
\hline \multirow[t]{2}{*}{ Petition } & FTDC & - & $\begin{array}{c}31.77 \\
(139.97)\end{array}$ & $\begin{array}{c}270.51 \\
(185.40)\end{array}$ & $\begin{array}{c}464.53 \\
(206.14)\end{array}$ & $\begin{array}{c}440.80 \\
(129.35)\end{array}$ & $\begin{array}{l}454.94^{*} \\
(228.47)\end{array}$ \\
\hline & Control & - & $\begin{array}{c}48.67 \\
(202.57)\end{array}$ & $\begin{array}{c}288.18 \\
(160.79)\end{array}$ & $\begin{array}{c}497.13 \\
(204.12)\end{array}$ & $\begin{array}{c}622.50 \\
(211.56)\end{array}$ & $\begin{array}{l}612.29^{*} \\
(346.40)\end{array}$ \\
\hline \multirow[t]{2}{*}{ Removal } & FTDC & - & - & $\begin{array}{c}262.01 \\
(185.03)\end{array}$ & $\begin{array}{c}530.00 \\
(207.02)\end{array}$ & $\begin{array}{c}431.20 \\
(126.78)\end{array}$ & $\begin{array}{l}492.92^{*} \\
(223.56)\end{array}$ \\
\hline & Control & - & - & $\begin{array}{c}357.07 \\
(230.80)\end{array}$ & $\begin{array}{c}531.69 \\
(108.02)\end{array}$ & $\begin{array}{c}677.75 \\
(197.72)\end{array}$ & $\begin{array}{l}635.67^{*} \\
(292.53)\end{array}$ \\
\hline \multirow[t]{2}{*}{ Reunification } & FTDC & - & - & - & - & - & $\begin{array}{l}135.55 \\
(104.29)\end{array}$ \\
\hline & Control & - & - & - & - & - & $\begin{array}{l}121.14 \\
(136.47)\end{array}$ \\
\hline \multirow[t]{2}{*}{$\begin{array}{l}\text { Voluntary } \\
\text { relinquishment }\end{array}$} & FTDC & - & - & - & - & - & $\begin{array}{c}151.02 \\
(98.08)\end{array}$ \\
\hline & Control & - & - & - & - & - & $\begin{array}{l}190.86 \\
(160.30)\end{array}$ \\
\hline \multirow[t]{2}{*}{ TPR } & FTDC & - & - & - & - & - & $\begin{array}{c}83.50 \\
(43.13)\end{array}$ \\
\hline & Control & - & - & - & - & - & $\begin{array}{r}684.00 \\
(0.00)\end{array}$ \\
\hline \multirow[t]{2}{*}{ Case closure } & FTDC & - & - & - & - & - & - \\
\hline & Control & - & - & - & - & - & - \\
\hline
\end{tabular}

The law requires the State to file a petition within 48 hours of removal in order to maintain temporary custody of a child (see Neb. Rev. Stat. 43-250(2) for the relevant statute for the current project). The petition to removal result is outside of the 48-hour rule because it includes the number of days for parents who were discovered and/or petitioned much later in the case. It is therefore being influenced by large outliers. At the case (rather than parent) level, the State removed FTDC children 9.19 days $(S D=59.74)$ and control children 38.22 days $(S D=74.96)$ after filing the first petition in the dependency court. Therefore, the 48 -hour rule is being complied with on the case level when controlling for later-identified parents. The State removed FTDC children from their parents' physical custody significantly sooner in the court process than control children, $F(1,182)=8.06$, $p=.01, \eta^{2}=.04$. Removal is the only date variable that is not parent-specific.

\section{Part 2: Parent surveys}

\section{Sample}

Parents participated in a total of 263 surveys $($ FTDC $=232$, control $=31$ ). They completed surveys an average of 212 days after their disposition hearing ( $S D=164.40$, range -98$1,008$, median $=174.00)$. Fifty-eight parents $(F T D C=55$, control $=3)$ completed a survey at 
multiple points in their case. We conducted within-groups ANOVAs examining parents' first survey and parents' most recently completed survey and found no significant differences in their perceptions over time $\left(p^{\prime} \mathrm{s}>.05\right)$. Therefore, we used the data from parents' most recently completed survey to conduct the following analyses. We limited these analyses to adjudicated parents because we were interested in the impact of mandatory participation on perceptions of procedural justice in the court process and nonadjudicated parents are not mandated to participate in the court process. This resulted in 159 unique surveys $(\mathrm{FTDC}=138$, control $=21)$. Most surveys $(71.07 \%)$ were completed by mothers; a smaller proportion $(28.93 \%)$ were completed by fathers.

\section{Procedure}

Research assistants attended in-court family team meetings and review hearings of both FTDC and control parents. Their goal was to survey parents three times throughout the length of their case at approximately 4-month intervals. Research assistants approached parents at the end of their hearing to request their participation. If parents agreed to participate, research assistants and the parent went into a nearby conference room where they could complete the survey in private. Research assistants reassured parents that their individual responses would not be shared with the judge or other parties and encouraged parents to be as honest as possible.

\section{Materials}

We created a short survey to measure parents' perceptions of the court process. Parents rated their agreement with 11 items on 5-point scales $(1=$ strongly disagree, $3=$ neither agree nor disagree, $5=$ strongly agree). The items measured the components of procedural justice, including voice, neutrality, trust, and respect (see Tyler and Blader 2003). Examples of the items included "The process of getting my children back is fair" and "I have a say in the decisions that affect me and my children." We calculated procedural justice scores by averaging parents' responses across all 11 items, which yielded high internal consistency (Cronbach's $\alpha=.93$ ). Higher scores indicated that parents perceived the court as more procedurally just and therefore more fair.

\section{Results}

Both FTDC parents and control parents had generally positive perceptions of the court. We conducted a series of between-group ANOVAs to determine if FTDC parents had different perceptions of the court process than control parents. Results are presented in Table 5. Although both groups shared generally positive perceptions of the court process, FTDC parents had significantly higher perceptions of procedural justice than control parents on five of 11 items: that the process was fair, their voice was heard in team meetings, they received praise from their caseworker, they received praise from the judge, and they could go to their caseworker with concerns. FTDC parents also had significantly higher average procedural justice scores $(M=4.31, S D=0.82)$ than control parents $(M=3.84, S D=0.99), F$ $(1,157)=5.71, p=.02, \eta^{2}=.04$. 
Table 5. Family Treatment Drug Court (FTDC) and traditional dependency court (control) parents' perceptions of procedural justice in the court process

\begin{tabular}{|c|c|c|c|c|c|c|}
\hline Item & & Mean (SD) & $\mathrm{df}$ & $F$ & $p$ & $\eta^{2}$ \\
\hline \multirow{2}{*}{$\begin{array}{l}\text { The process of getting my children back } \\
\text { is fair. }\end{array}$} & FTDC & $3.98(1.24)$ & 1,157 & 3.99 & $.048^{*}$ & .03 \\
\hline & Control & $3.38(1.50)$ & & & & \\
\hline \multirow{2}{*}{$\begin{array}{l}\text { I am comfortable speaking at family } \\
\text { team meetings. }\end{array}$} & FTDC & $4.25(1.12)$ & 1,157 & 1.66 & .20 & .01 \\
\hline & Control & $3.90(1.22)$ & & & & \\
\hline \multirow{2}{*}{$\begin{array}{l}\text { My voice is heard at family team } \\
\text { meetings. }\end{array}$} & FTDC & $4.33(0.98)$ & 1,157 & 13.60 & $<.001^{*}$ & .08 \\
\hline & Control & $3.43(1.40)$ & & & & \\
\hline \multirow{2}{*}{$\begin{array}{l}\text { I have a say in the decisions that affect } \\
\text { me and my children. }\end{array}$} & FTDC & $3.99(1.13)$ & 1,157 & 2.33 & .13 & .02 \\
\hline & Control & $3.57(1.40)$ & & & & \\
\hline \multirow[t]{2}{*}{ I can be honest in team meetings. } & FTDC & $4.48(0.87)$ & 1,157 & 0.06 & .81 & $<.01$ \\
\hline & Control & $4.34(0.93)$ & & & & \\
\hline \multirow{2}{*}{$\begin{array}{l}\text { The main goal of this process is to get } \\
\text { my children returned to me. }\end{array}$} & FTDC & $4.68(0.75)$ & 1,157 & 0.36 & .55 & $<.01$ \\
\hline & Control & $4.57(0.98)$ & & & & \\
\hline \multirow{2}{*}{$\begin{array}{l}\text { I have access to the services that I need } \\
\text { to get my children returned to me. }\end{array}$} & FTDC & $4.36(1.06)$ & 1,157 & 1.01 & .30 & .01 \\
\hline & Control & $4.10(1.30)$ & & & & \\
\hline \multirow{2}{*}{$\begin{array}{l}\text { I know what needs to be done to get my } \\
\text { children returned to me. }\end{array}$} & FTDC & $4.59(0.84)$ & 1,157 & 0.36 & .55 & $<.01$ \\
\hline & Control & $4.48(0.81)$ & & & & \\
\hline \multirow{2}{*}{$\begin{array}{l}\text { I receive praise from my caseworker } \\
\text { when I make process toward my goals. }\end{array}$} & FTDC & 4.17 (1.27) & 1,157 & 5.90 & $.02^{*}$ & .04 \\
\hline & Control & $3.43(1.47)$ & & & & \\
\hline \multirow{2}{*}{$\begin{array}{l}\text { I receive praise from the judge when I } \\
\text { make progress toward my goals. }\end{array}$} & FTDC & $4.48(1.01)$ & 1,157 & 12.33 & $<.001^{*}$ & .07 \\
\hline & Control & $3.62(1.28)$ & & & & \\
\hline \multirow{2}{*}{$\begin{array}{l}\text { I can to go my caseworker with any } \\
\text { concerns I have about my ability to } \\
\text { meet my goals. }\end{array}$} & FTDC & 4.07 (1.28) & 1,157 & 6.47 & $.01^{*}$ & .04 \\
\hline & Control & 3.29 (1.49) & & & & \\
\hline
\end{tabular}

\section{Part 3: Mediation analyses}

\section{Sample}

The mediation analyses are limited to a subsample of 168 adjudicated parents (FTDC $=145$, $86.31 \%$, control $=23,13.70 \%$ ) for whom we had data for at least two of the three variables included in the model: average service participation, case outcome, and procedural justice score. This included 117 mothers (69.64\%) and 51 fathers (30.36\%). Following casewise deletion of missing data in the mediation analyses with a weighted least-square means and variance (WLSMV) estimator (see further discussion below), the subsample included 147 
adjudicated parents $($ FTDC $=129$, control $=18)$, which included $106(72.12 \%)$ mothers and $41(27.89 \%)$ fathers.

\section{Method}

We conducted the mediation analyses using parents' court group, average service participation, case outcomes, time to case outcomes, and procedural justice scores. We dummycoded court group to capture which court process the parents were following $(0=$ control, $1=$ FTDC).

We used parents' average service participation scores reported in Part 1. This score was an average of how consistently parents participated in court-ordered services in the most recent six-month reporting period. Higher numbers indicate more consistent participation $(0=$ did not participate, 3 = completed participation).

We also used parents' case outcomes and time to case outcomes reported in Part 1. We were specifically interested in whether the parents reunified with their children, whether the case closed successfully, and the number of days that elapsed between the date the petition was filed and these milestones. Reunification occurred when the court returned physical custody of the children back to the parent $(0=$ not reunified, $1=$ reunified). Successful case closure occurred when the court terminated its jurisdiction over the family following reunification $(0=$ unsuccessful case closure, $1=$ successful case closure $)$. We recorded time to case outcomes in the number of days and therefore lower numbers indicated the parents met milestones earlier and the children waited less time for permanency.

Finally, we used parents' procedural justice scores reported above in Part 2. This score was a composite variable (Cronbach's $\alpha=.93$ ) created by combining responses to the 11-item survey. Higher numbers indicate higher perceptions of procedural justice ( $1=$ strongly disagree, 5 = strongly agree).

\section{Analysis}

We used structural equation modeling (SEM) in MPlus 7 (Muthén and Muthén 2010) with weighted least-square means and variance (WLSMV) estimator to test the hypothesis that FTDC parents would reunify more often and sooner than control parents because they perceived the process as more fair and, therefore, participated more consistently in courtordered services. We had $5.36 \%$ missing data for average service participation scores, $5.36 \%$ missing data for procedural justice scores, $2.38 \%$ missing data for reunification, and $0.0 \%$ missing for successful case closure. The WLSMV estimator was used because reunification and successful case closure are categorical variables (Muthén 1984). The WLSMV estimator does not allow missing data and, therefore, cases with missing data were excluded from the model casewise. Casewise deletion is appropriate when there is less than 10\% missing data (Langkamp et al. 2010).

First, preliminary analyses and descriptive statistics tested whether the data met the basic assumptions of SEM. Next, serial mediation analyses tested the hypothesized models (see Fig. 1) with a bootstrapped approach (Shrout and Bolger 2002). The bootstrapped approach maximizes statistical power through resampling which minimizes the risk of type I errors and creates confidence intervals (CIs) through empirical approximation of sampling distributions of indirect effects (Shrout and Bolger 2002). Nonparametric resampling 
methods (bias-corrected bootstrap) with 5000 samples drawn to derive the $95 \%$ CIs were used for the modeled direct and indirect effects of court group on reunification.

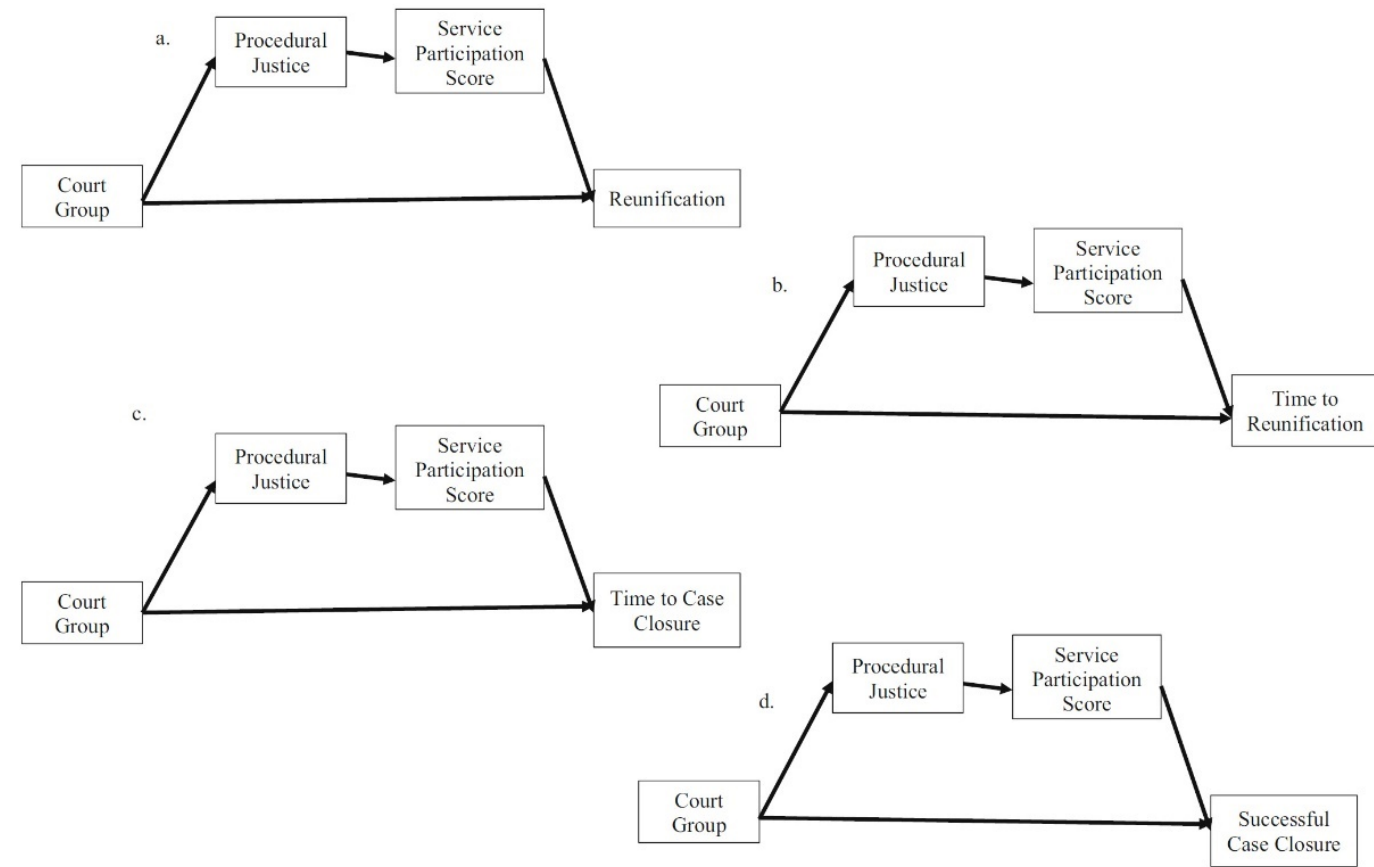

Figure 1. Hypothesized models of serial mediation from court group (Family Treatment Drug Court versus traditional dependency court) to reunification, time to reunification, and time to case closure.

\section{Results}

Correlations and descriptive statistics confirmed the data met the basic assumptions of SEM for the model predicting reunification, but not for time to reunification, case closure, or successful case closure (see Table 6). There were significant positive linear relationships between court group and reunification, average service participation scores, and procedural justice scores. Further, there were significant positive linear relationships between reunification and average service participation scores and procedural justice scores. Finally, there was a significant positive linear relationship between average service participation scores and procedural justice scores. Average service participation scores were highly correlated with reunification $(r>.70)$. Further, partial correlations between court group and reunification, controlling for procedural justice score and average service participation scores together and independently remained moderate and significant. When controlling for procedural justice scores, court group is significantly and positively correlated with reunification $(r=.29, p<.001)$. When controlling for average service participation scores, court group is significantly and positively correlated with reunification $(r=.32$, $p<.001)$. When controlling for both procedural justice scores and average service participation, court group is significantly and positively correlated with reunification $(r=.31, p<$ 
.001). Due to these findings, we ran SEM for the serial mediation of procedural justice score and average service participation score between court group and reunification. We did not test the mediation analyses for the outcomes that were not correlated with court group because the assumption of a linear relationship between the predictor variable and the dependent variable was not met (MacCullum and Austin 2000).

Table 6. Correlations between court group (Family Treatment Drug Court as "FTDC"; Traditional Dependency Court as "control"), case outcomes, participation scores, and perceptions of procedural justice

\begin{tabular}{|c|c|c|c|c|c|c|c|c|c|c|}
\hline & $N$ & $\begin{array}{c}M \\
(S D)\end{array}$ & Frequency & 1 & 2 & 3 & 4 & 5 & 6 & 7 \\
\hline 1. Court group & 168 & & $\begin{array}{l}\text { FTDC }(1)=145(86.3 \%) \\
\text { Control }(0)=23(13.7 \%)\end{array}$ & - & & & & & & \\
\hline 2. Reunification & 164 & & $\begin{array}{l}\text { Yes }(1)=67(39.9 \%) \\
\text { No }(0)=97(57.7 \%)\end{array}$ & $.16^{*}$ & - & & & & & \\
\hline $\begin{array}{l}\text { 3. Successful } \\
\text { case closure }\end{array}$ & 168 & & $\begin{array}{l}\text { Yes }(1)=56(33.3 \%) \\
\text { No }(0)=110(66.3 \%)\end{array}$ & .05 & $-.20^{*}$ & - & & & & \\
\hline $\begin{array}{l}\text { 4. Days from petition } \\
\text { to reunification }\end{array}$ & 65 & $\begin{array}{c}313.35 \\
(183.56)\end{array}$ & & -.04 & - & -.15 & - & & & \\
\hline $\begin{array}{l}\text { 5. Days from petition } \\
\text { to case closure }\end{array}$ & 108 & $\begin{array}{c}535.16 \\
(227.50)\end{array}$ & & -.13 & $-.43^{* * *}$ & $-.41^{* * *}$ & $-.81^{* * *}$ & - & & \\
\hline $\begin{array}{l}\text { 6. Average service } \\
\text { participation }\end{array}$ & 159 & $\begin{array}{c}1.71 \\
(0.98)\end{array}$ & & $.19^{*}$ & $.76^{* * *}$ & $.61^{* * *}$ & $-.21^{*}$ & $-.35^{* * *}$ & - & \\
\hline $\begin{array}{l}\text { 7. Procedural } \\
\text { justice score }\end{array}$ & 159 & $\begin{array}{c}4.42 \\
(0.85)\end{array}$ & & $.19^{*}$ & $.24^{* *}$ & $.23^{* *}$ & -.02 & -.15 & $.29^{* * * *}$ & - \\
\hline
\end{tabular}

${ }^{*} p<.05,{ }^{* *} p<.01,{ }^{* * *} p<.001 ;$ correlations run in SPSS

The reunification model was just-identified, resulting in perfect global fit, $\chi^{2}(6, n=168)$ $=116.20, p=0.00, \mathrm{CFI}=1.00, \mathrm{TLI}=1.00, \mathrm{RMSEA}=0.00, \mathrm{WRMR}=0.00$. Standardized path coefficients are reported in Fig. 2 and unstandardized coefficients (and SEs) are reported in Table 7. Results revealed a serial mediation of court group on reunification through procedural justice scores and average service participation scores. The model explained $3.60 \%$ in the variance of procedural justice scores, $10.70 \%$ of the variance in average service participation scores, and $81.20 \%$ of the variance in reunification. 


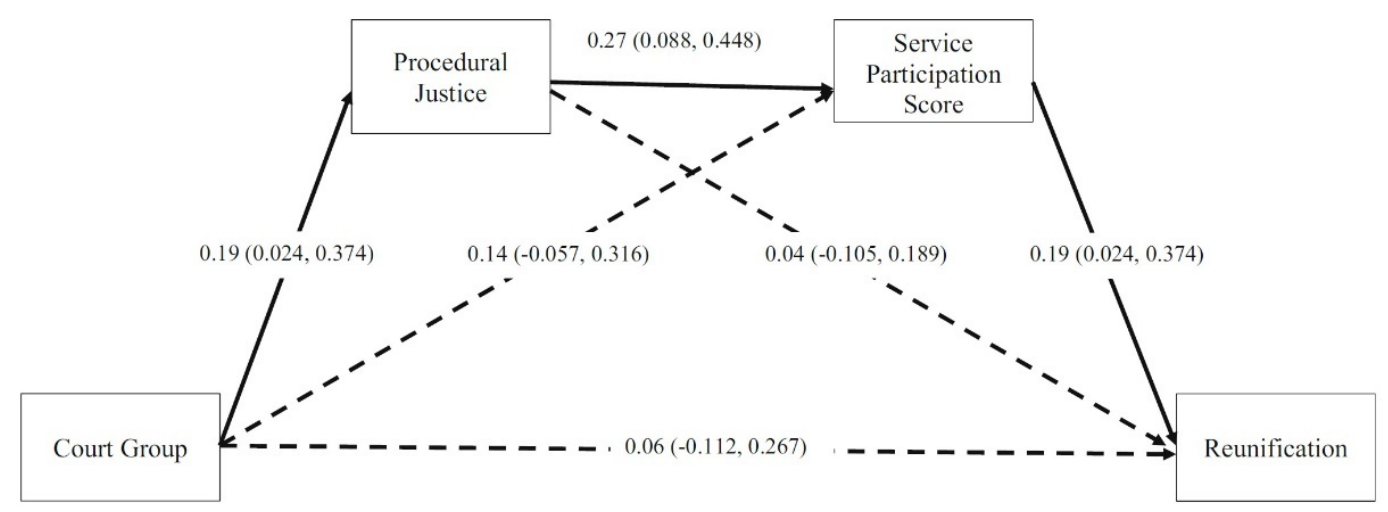

Indirect effect of court group on reunification through procedural justice scores: $0.01 \mathrm{CI} 95 \%$ [-0.018, 0.051$]$

Indirect effect of court group on reunification through service participation scores: $0.12 \mathrm{CI} 95 \%$ [-0.015, 0.280$]$

Indirect effect of court group on reunification through procedural justice scores and service participation scores: $0.05 \mathrm{CI} 95 \%$ [0.005, 0.125$]$

Total indirect of court group on reunification: 0.17 CI 95\% [-0.008, 0.336]

Total effect of court group on reunification: 0.23 CI $95 \%[0.025,0.449]$

Figure 2. Representing each unique model pathway of the serial mediation of court group on reunification through procedural justice scores and average participation scores. Nonsignificant pathways (CI 95\%) are represented with dotted lines and significant pathways (CI 95\%) are represented with solid lines. Standardized path coefficients and CI 95\% are reported.

Table 7. Unstandardized coefficient and standard errors representing each unique modeled pathway between court group (Family Treatment Drug Court versus traditional dependency court) and reunification through procedural justice and average service participation score

\begin{tabular}{|c|c|c|}
\hline & Estimate & Standard error \\
\hline \multicolumn{3}{|l|}{ Reunification on } \\
\hline Court group & 0.18 & 0.31 \\
\hline Procedural justice & 0.04 & 0.09 \\
\hline Average service participation & $0.92^{*}$ & 0.05 \\
\hline \multicolumn{3}{|l|}{ Participation on } \\
\hline Court group & 0.38 & 0.28 \\
\hline Procedural justice & $0.32^{*}$ & 0.12 \\
\hline \multicolumn{3}{|l|}{ Procedural justice on } \\
\hline Court group & $0.47^{*}$ & 0.23 \\
\hline
\end{tabular}

Asterisk indicates significant at $95 \%$ confidence interval.

The total effect of court group on reunification is present, $0.23,95 \% \mathrm{CI}[0.025,0.449]$. The total effect of court group on reunification, considering the influences of procedural justice scores and average service participation scores, is absent, $0.17,95 \%$ CI $[-0.008,0.336]$. Therefore, when including perceptions of procedural justice in the court process and the 
consistency with which parents participated in court-ordered services, the FTDC did not increase the likelihood of reunification. However, the serial mediation effect of court group on reunification through procedural justice scores and average service participation scores was present, $0.0595 \%$ CI [0.005, 0.125]. Therefore, FTDC parents perceived the court process as more fair than control parents, which led to higher average service participation, which in turn led to more parent-child reunifications.

\section{Discussion}

The Lancaster County Family Treatment Drug Court (FTDC) is a mandatory problem-solving court that serves parents who have lost physical custody of their children because of substance use. The present program evaluation examined the outcomes and mechanisms of the FTDC to examine whether the positive outcomes of problem-solving courts replicate when participants are mandated to participate. Overall, our results demonstrated that a problem-solving court can still promote procedural justice and positive case outcomes even when participation is mandatory.

The results mostly supported our hypotheses.We found that FTDC parents were more compliant with court-ordered evaluations than control parents but just as compliant with court-ordered services. We also found that FTDC parents' cases closed faster than control parents' cases. These were both likely due to the regular and frequent court contact.

We also found that all parents perceived the court process as fair, but that FTDC parents had significantly more positive perceptions of the court than control parents. This was consistent with past research (Frazer 2006; Gottfredson et al. 2007; Gover et al. 2007; Kaiser and Holtfreter 2016; McIvor 2009; Roman et al. 2011; Wales et al. 2010; Wiener et al. 2010) and demonstrates that a problem-solving court can still promote procedural justice when participation is mandatory. The more frequent and less formal court contact (i.e., in-court family team meetings) provided FTDC parents opportunities to express their preferences and to engage with team members in court that control parents did not have. Specifically, FTDC parents agreed more than control parents that their voice was heard during family team meetings and felt more positively toward the judge and their caseworker. These findings further highlight the important role of voice and relationships between professionals and parents in promoting fairness in the court process.

Further, we also replicated previous findings that procedural justice and compliance with court orders mediated the relationship between court group and positive case outcomes (i.e., reunification) (Frazer 2006; Gottfredson et al. 2007; Gover et al. 2007; McIvor 2009). However, we did not replicate this finding for time to case outcomes or successful case closure. FTDC parents were more likely than control parents to reunify with their children because they perceived the court process as more fair and, as a result, participated in services more consistently. Therefore, the mandatory nature of the FTDC did not interfere with the established positive effects of therapeutic jurisprudential approaches on perceptions of fairness in the court process, and also did not eliminate procedural justice as the mechanism for positive case outcomes.

There was initial concern that the mandatory nature of the FTDC would interfere with parents' cooperation and compliance with court orders, but this concern was not reflected 
in our data. Therefore, although scholars emphasize voluntary enrollment as critical to promoting procedural justice in problem-solving courts (Redlich 2010; Wiener et al. 2010), we found that a mandatory problem-solving court was still able to promote procedural justice in a way that led to positive case outcomes. FTDC parents may have perceived the court process as fair despite their mandatory participation because the initial decision to participate is not the only way to ensure voice in the court process. FTDC parents had many opportunities to express their voice throughout the court process during the monthly family team meetings and the regular and less formal contact between parents and the judge, attorneys, caseworkers, and other parties.

It is important to note that describing any court process as voluntary fails to recognize that none of the participants actually have a choice about being court involved and ignores the inherently coercive nature of making a deal with the government to dismiss criminal charges (Frailing 2010; Redlich 2010). Regardless of which court process the participant "chooses" to use, they may be required to complete the same types of treatments and make the same lifestyle changes. Problem-solving courts simply adapt the process and provide support based on strategies found to be more humane and to encourage compliance.

Problem-solving courts are often surrounded by concerns about due process protections because participants are asked to waive numerous procedural rights (e.g., right to trial, right to a jury, right against compelled self-incrimination) (Quinn 2001). Scholars often counter due process concerns by emphasizing that voluntary enrollment is a functional waiver of the associated procedural rights and therefore adequately addresses those concerns (Brank and Haby 2010). This may leave some wondering whether the mandatory program discussed here protects due process rights of parents. In criminal courts, voluntary participation furthers constitutional protections associated with the due process of law by allowing individuals to make an explicit and informed waiver of their protections (Quinn 2001). It is important to note that the FTDC is a dependency court within the juvenile court system, where the rules of evidence apply differently under the law and due process protections are less rigorous (L.L. v. Colorado 2000; Santosky v. Kramer 1982).

Further, two features of the FTDC ensure that due process rights of parents in juvenile court are protected to the same extent as the control parents. First, the juvenile courts operate through the parens patriae powers of the government. Parens patriae is the authority to provide for the general welfare and intervene when an individual cannot provide for their own or a dependent's welfare. This authority is limited and considered a civil issue that requires fewer procedural protections under the law. Second, the program formally begins after the dispositional hearings. Therefore, unlike criminal problem-solving courts, the program does not begin until after parents have been adjudicated responsible for child abuse or neglect and after the initial rehabilitation plan is created. Thus, FTDC parents are not pleading guilty to join the program and do not have the threat of formal prosecution lingering. The facts of the case are decided in accordance with the requirement of due process for child dependency court.

Second, the court orders FTDC parents to participate in more services than control parents as evidenced by a significant difference in the number of dispositional orders. However, those additional services are inherent in the FTDC program, including in-court family team meetings and substance use treatment. Despite the additional orders, FTDC parents 
still perceived the court process as more fair than control parents. Therefore, although juvenile courts are held to lesser procedural protections than criminal courts, the FTDC provides the same procedural protections as the traditional dependency court process without resulting in more negative perceptions of the process.

\section{Methodological considerations}

It is important to discuss the strengths and limitations of our methodology when considering the practical and theoretical implications of this evaluation. This was the first evaluation, to our knowledge, to examine a mandatory family drug court. In light of this, more work on mandatory problem-solving courts is needed before broad generalizations are made from these results.

The first and major limitation of the present evaluation is that we did not directly compare the effects of voluntary and mandatory participation in a problem-solving court. Therefore, the results of the present evaluation should not be interpreted to suggest that one form of enrollment is more effective than the other. However, what the results do suggest is that a mandatory problem-solving court can still promote procedural justice in ways observed in voluntary problem-solving courts. Future development of problem-solving courts should consider whether voluntary participation fits the model of the program and, if mandatory participation is necessary, should ensure that there are other ways to promote procedural justice.

Moreover, we conducted this project as part of a program evaluation of the Lancaster County Family Treatment Drug Court (FTDC). It therefore represents only the experiences of parents in one program. This allowed us to have fairly open access to both the parents and the court records necessary to conduct the present evaluation but may not generalize to other courtrooms, other types of problem-solving courts, or other jurisdictions. It does, however, provide at least one demonstration of a mandatory problem-solving court that works effectively for participants.

We also acknowledge limitations in the control group. First, the FTDC is mandatory so we used a quasi-experimental design without a "pure" control group. Although propensity score matching was not indicated by the data, the control parents were different from FTDC parents because they did not have allegations of substance use in their child abuse/ neglect petition. Therefore, the adjudicated issue addressed by the court process was fundamentally different in kind and treatment for control parents than FTDC parents. This meant we could not identify whether parents on the FTDC were more successful in their drug treatment programs or case outcomes than they would have been had they followed the traditional dependency court process. We also could not identify whether the control parents would have been more successful in their rehabilitation plan had they had the same processes as the FTDC parents. The control parents did allow us to make meaningful comparisons, however, because they followed the traditional dependency court process, were demographically comparable, and sat in front of the same judge as FTDC parents. Second, this was a program evaluation of the FTDC so we were able to identify FTDC parents more easily than control parents. This left us with a larger sample of FTDC parents than control parents. Although the proportion of FTDC parents to control parents was 
skewed, we did have large enough groups to conduct most significance tests and to detect several medium-sized effects.

It is important to note that our survey results rely on a subsample of FTDC and control parents. We invited parents to complete our survey following in-court family team meetings or review hearings. However, parents were not always present in court. Additionally, a small portion of parents declined to complete surveys. They provided various justifications when declining to participate, such as having limited time or not being interested. Additionally, despite considerable effort, research assistants were unable to attend every in-court family team meeting or review hearing, which meant some missed data collection opportunities. Therefore, our sample of parents surveyed may be biased by their willingness to complete the survey and toward parents more engaged in the court process. Both of these biases would result in more positive perceptions of the court. However, this is true for both FTDC and control parents and therefore should not impact observed differences between the two groups.

This sampling bias may have also impacted the mediation analysis. Parents included in the model included those who completed at least one survey. They were more likely to be attending court and therefore may have been more likely to be participating in services and following court orders. As a legal fact, these parents would also be likely to be reunified as a consequence of their engagement. However, descriptive statistics from parents who completed the survey illustrated variability in their perceptions of court, average service participation, and reunification. The bias introduced by the subsample willing to complete surveys would be expected to average across court groups.

Lastly, we collected most of this data from court records. This allowed us to gather a record of parents' court orders and case progression as well as objective data on whether they were participating in services. This did, however, limit us to the information present in the court's official documentation, which may not have fully captured parents' experiences with the court. This was evidenced by a small proportion of parents' participation in services missing from their case plans. While some information was missing, most of the information was present in the court records, meaning both that the court had a record of parents' progress toward reunification and that we could collect a record for the present evaluation.

Overall, there were both strengths and limitations in the methodology we employed in the present evaluation. We believe it provides a strong foundation that can inform future work on problem-solving courts but is not definitive on whether mandatory problem-solving courts will work in all applications.

\section{Conclusion}

Much of the research on problem-solving courts focuses on whether their models holistically perform better than their traditional counterparts. However, problem-solving courts are made up of several components that differentiate them from traditional courts. Problemsolving courts adhering to the same key components often implement them in very different ways (Carey et al. 2008; Green et al. 2009). Therefore, it is important to maintain flexibility in the implementation of a problem-solving court so that it can work in ways that 
consider the needs of a specific population or jurisdiction. The Lancaster County FTDC and the results of the presented evaluation are a prime example of this idea. Although the literature on problem-solving courts emphasizes the need for voluntary participation, the Lancaster County FTDC demonstrated that a problem-solving court can still promote procedural justice and positive case outcomes without this requirement. It will be important for future research to continue breaking apart the specific components of problem-solving courts to determine which are essential to their efficacy and which can be tailored to meet the court's specific needs.

Courts across the country are shifting their focus away from punishment and toward rehabilitation in order to promote positive and long-term outcomes. Family drug courts, in particular, are developing and using innovative methods of addressing substance use to rehabilitate parents, reunite families, and prevent recidivism. The Lancaster County Family Treatment Drug Court provides one example of how these problem-solving courts can adapt their processes and continue to effectively serve parties to successfully work toward their goals.

Acknowledgments - This program evaluation was made possible by a Drug Court Enhancement Grant from the Office of Juvenile Justice \& Delinquency Prevention (C-16-0724) of the United States Department of Justice; The Nebraska Resource Project for Vulnerable Young Children; The University of Nebraska Center on Children, Families, and the Law; and the Nebraska Court Improvement Project. Additionally, the authors would like to thank the attorneys; Department of Health and Human Services caseworkers, supervisors, and administrators; court administrators and staff; research assistants; and families of Lancaster County, Nebraska, for their dedication and determination to making this project a success.

\section{References}

Ashford, J. B. (2004). Treating substance-abusing parents: a study of the Pima County family drug court approach. Juvenile and Family Court Journal, 55(4), 27-37.

Barth, R., Gibbons, C., \& Guo, S. (2006). Substance abuse treatment and the recurrence of maltreatment among caregivers with children living at home: a propensity score analysis. Journal of Substance Abuse Treatment, 30(2), 93-104.

Berkowitz, G., Brindis, C., Clayson, Z., \& Peterson, S. (1996). Options for recovery: promoting success among women mandated to treatment. Journal of Psychoactive Drugs, 28(1), 31-38.

Boles, S. M., Young, N. K., Moore, T., \& DiPirro-Beard, S. (2007). The Sacramento dependency drug court: development and outcomes. Child Maltreatment, 12(2), 161-171.

Bradford, B. (2014). Policing and social identity: procedural justice, inclusion and cooperation between police and the public. Police and Society, 24(1), 22-43.

Brank, E. M., \& Haby, J. A. (2010). The intended and unintended consequences of problem-solving courts. In R. L. Wiener \& E. M. Brank (Eds.), Problem solving courts: Social science and legal perspectives (pp. 239-251). New York, NY: Springer.

Brecht, M. L., Anglin, D., \& Wang, J. (1993). Treatment effectiveness for legally coerced versus voluntary methadone maintenance clients. American Journal of Drug and Alcohol Abuse, 19(1), 89-106.

Breitenbucher, P., Pfeifer, J., \& Wheeler, M. (2018). Beyond guidance: a sneak preview of upcoming national FDC standards. Training session presented at 2018 National Association of Drug Court Professionals 
Annual Training Conference, Houston, Texas. Retrieved on June 1, 2018, from http://www .nadcpconference.org/wp-content/uploads/2018/05/TS-13-1.pdf

Bruns, E. J., Pullmann, M. D., Weathers, E. S., Wirschem, M. L., \& Murphy, J. K. (2012). Effects of a multidisciplinary Family Treatment Drug Court on child and family outcomes: results of a quasiexperimental study. Child Maltreatment, 17(3), 218-230.

Carey, S. M., Finigan, M. W., \& Pukstas, K. (2008). Exploring the key components of drug courts: a comparative study of 18 adult drug courts on practices, outcomes and costs. Portland, OR: NPC Research. Retrieved on June 1, 2018, from https://www.ncjrs.gov/pdffiles1/nij/grants/223853.pdf

Carey, S. M., Sanders, M. B.,Waller, M., Burrus, S.W. M., \& Aborn, J. A. (2010). Jackson county community family court-process, outcome, and cost evaluation: final report. Portland, OR: NPC Research. Retrieved on June 1, 2018, from http://npcresearch.com/wp-content/uploads/Jackson_Byrne_06101.pdf

Child Welfare Information Gateway. (2014). Parental substance use and the child welfare system. Washington, DC: U.S. Department of Health and Human Services, Children's Bureau. Retrieved on June 1, 2018, from https://www.childwelfare.gov/pubPDFs/parentalsubabuse.pdf

Copeland, J., \& Maxwell, J. C. (2007). Cannabis treatment outcomes among legally coerced and noncoerced adults. BMC Public Health, 7, 111-118.

Farabee, D., Prendergast, M., \& Anglin, M. D. (1998). The effectiveness of coerced treatment for drug abusing offenders. Federal Probation, 62(1), 3-10.

Frailing, K. (2010). How mental health courts function: outcomes and observations. International Journal of Law and Psychiatry, 33(4), 207-213.

Frazer, M. S. (2006). The impact of the community court model on defendant perceptions of fairness: a case study at the Red Hook Community Justice Center. New York, NY: Center for Court Innovation.

Gatowski, S. I., Dobbin, S. A., \& Summers, A. (2013). Exploring the value-added of specialized problemsolving courts for dependency cases. In R. L. Wiener \& E. M. Brank (Eds.), Problem solving courts: Social science and legal perspectives (pp. 33-53). New York, NY: Springer.

Gerber, M. M., González, R., Carvacho, H., Jiménez-Moya, G., Moya, C., \& Jackson, J. (2018). On the justification of intergroup violence: the roles of procedural justice, police legitimacy, and group identity in attitudes toward violence among indigenous people. Psychology of Violence, 8(3), 379-389.

Gottfredson, D. C., Kearly, B.W., Najaka, S. S., \& Rocha, C. M. (2007). How drug treatment courts work: an analysis of mediators. Journal of Research in Crime and Delinquency, 44(1), 3-35.

Gover, A. R., Brank, E. M., \& MacDonald, J. M. (2007). A specialized domestic violence court in South Carolina: an example of procedural justice for victims and defendants. Violence Against Women, 13(6), 603-626.

Green, B. L., Furrer, C. J.,Worcel, S. D., Burrus, S. W. M., \& Finigan, M. W. (2007). How effective are family treatment drug courts? Results from a 4-site national study. Child Maltreatment, 12(1), 43-59.

Green, B. L., Furrer, C. J., Worcel, S. D., Burrus, S. W. M., \& Finigan, M. W. (2009). Building the evidence base for family drug treatment courts: results from recent outcome studies. Drug Court Review, 6(2), 53-82.

Hiller, M. L., Knight, K., Broome, K. M., \& Simpson, D. D. (1998). Legal pressure and treatment retention in a national sample of long-term residential programs. Criminal Justice and Behavior, 25, 463-481.

Howard, D. L., \& McCaughrin, W. C. (1996). The treatment effectiveness of outpatient substance misuse treatment organizations between court-mandated and voluntary clients. Substance Use \& Misuse, 31(7), 895-926. 
Kaiser, K. A., \& Holtfreter, K. (2016). An integrated theory of specialized court programs: using procedural justice and therapeutic jurisprudence to promote offender compliance and rehabilitation. Criminal Justice and Behavior, 43(1), 45-62.

King, M. S. (2008). Restorative justice, therapeutic jurisprudence and the rise of emotionally intelligent justice. Melbourne University Law Review, 32, 1096-1126.

Klag, S., O'Callaghan, F., \& Creed, P. (2005). The use of legal coercion in the treatment of substance abusers: an overview and critical analysis of thirty years of research. Substance Use and Misuse, 40, 1777-1795.

L.L. v. Colorado. 10 P.2d 1271 (2000).

Langkamp, D. L., Lehman, A., \& Lemeshow, S. (2010). Techniques for handling missing data in secondary analysis with large surveys. Academic Pediatrics, 10(3), 205-210.

Lind, E. A., Tyler, T. R., \& Huo, Y. J. (1997). Procedural context and culture: variation in the antecedents of procedural justice judgements. Journal of Personality and Social Psychology, 73(4), 767-780.

Looney, M., \& Metcalf, S. (1974). The "fatigue factor" in drug addiction: insufficient motive for treatment. Hospital Community Psychiatry, 23, 528-530.

MacCullum, R. C., \& Austin, J. T. (2000). Applications of structural equation modeling in psychological research. Annual Review of Psychology, 51, 201-226.

MacKenzie, B. (2016). The judge is the key component: the importance of procedural fairness in drugtreatment courts. Court Review, 52, 8-33.

Maddux, J. F. (1988). Clinical experience with civil commitment. In C. G. Leukefeld \& F. M. Tims (Eds.), Compulsory treatment of drug abuse: research and clinical practice. NIDA Monograph No. 86 (pp. 35-56). Rockville, MD: NIDA.

Marlowe, D. B., \& Carey, S. M. (2012). Research update on family drug courts. Alexandria, VA: National Association of Drug Court Professionals. Retrieved on June 1, 2018, from http://www.nadcp.org/ wpcontent/uploads/Reseach\%20Update\%20on\%20Family\%20Drug\%20Courts\%20-\%20NADCP.pdf

McIvor, G. (2009). Therapeutic jurisprudence and procedural justice in Scottish drug courts. Criminology and Criminal Justice, 9(1), 29-49.

Muthén, B. (1984). A general structural equation model with dichotomous, ordered categorical, and continuous latent variable indicators. Psychometrika, 49, 115-132.

Muthén, L., \& Muthén, B. (2010). Mplus user's guide (6th ed.). Los Angeles: Muthén \& Muthén.

National Institute on Drug Abuse. (2018). Principles of drug addiction treatment: a research-based guide (Third ed.) Retrieved from https://www.drugabuse.gov/publications/principles-drug-addictiontreatment-research-based-guide-third-edition/principles-effective-treatment

Neb. Rev. Stat. § 43-250(2). Retrieved on June 1, 2018, from https://nebraskalegislature.gov/laws/statutes .php?statute $=43-250$

Oliveros, A., \& Kaufman, J. (2011). Addressing substance abuse treatment needs of parents involved with the child welfare system. Child Welfare, 90(1), 25-41.

Perron, B. E., \& Bright, C. L. (2008). The influence of legal coercion on dropout from substance abuse treatment: results from a national survey. Drug and Alcohol Dependence, 92(1-3), 123-131.

Poythress, N. G., Petrila, J., McGaha, A., \& Boothroyd, R. (2002). Perceived coercion and procedural justice in the Broward mental health court. International Journal of Law and Psychiatry, 25, 517-533.

Prendergast, M. L., Farabee, D., Cartier, J., \& Henkin, S. (2002). Involuntary treatment within a prison setting: impact on psychosocial change during treatment. Criminal Justice and Behavior, 29(1), 5-26.

Quinn, M. C. (2001). Whose team am I on anyway? Musings of a public defender about drug treatment court practice. New York University Review of Law and Social Change, 26, 37-75. 
Redlich, A. (2010). The past, present, and future of mental health courts. In R. L. Wiener \& E. M. Brank (Eds.), Problem solving courts: social science and legal perspectives (pp. 147-161). New York, NY: Springer.

Rempel, M., \& Destefano, C. D. (2001). Predictors of engagement in court-mandated treatment. Journal of Offender Rehabilitation, 33(4), 87-124.

Roman, J. K., Yahner, J., \& Zweig, J. M. (2011). How do drug courts work? In Rossman, S. B., Roman, J. K., Zweig, J. M., Rempel, M., \& Lindquist, C. H. (Eds.), The multi-site adult drug court evaluation: the impact of drug courts (pp. 92-120). Urban Institute: Justice Policy Center.

Rosenthal, M. P. (1988). The constitutionality of involuntary civil commitment of opiate addicts. Journal of Drug Issues, 18(4), 641-661.

Santosky v. Kramer. 455 U.S. In 745 (1982).

Shrout, P. E., \& Bolger, N. (2002). Mediation in experimental and nonexperimental studies: new procedures and recommendations. Psychological Methods, 7(4), 422.

Spencer, P. (2012). To dream the impossible dream? Therapeutic jurisprudence in mainstream courts (2012). International Conference on Law and Society. Retrieved on February 1, 2019, from https://papers .ssrn. com/sol3/papers.cfm?abstract_id=2083370

Tyler, T. R. (1989). The psychology of procedural justice: a test of the group-value model. Journal of Personality and Social Psychology, 57(3), 830-838.

Tyler, T. R., \& Blader, S. L. (2003). The group engagement model: procedural justice, social identity, cooperative behavior. Personality and Social Psychology Review, 7(4), 349-361.

Tyler, T. R., \& Huo, Y. J. (2002). Trust in the law: encouraging public cooperation with the police and courts. New York, NY: Russell Sage Foundation.

United States Department of Health and Human Services (DHHS). (1999). Blending perspectives and building common ground: a report to congress on substance abuse in child protection. Washington, D.C.: U.S. Government Printing Office.

United States General Accounting Office (GAO). (1998). Foster care agencies face challenges securing stable homes for children of substance abusers. GAO/HEHS-98-182. Washington, D.C.: U.S. Government Printing Office.

Wales, H. W., Hiday, V. A., \& Ray, B. (2010). Procedural justice and the mental health court judge's role in reducing recidivism. International Journal of Law and Psychiatry, 33, 265-271.

West, S. G., Cham, H., \& Liu, Y. (2014a). Causal inference and generalization in field settings: experimental and quasi-experimental designs. In H. T. Reis \& C. M. Judd (Eds.), Handbook of research methods in social and personality psychology (2nd ed., pp. 49-80). New York, NY: Cambridge University Press.

West, S. G., Cham, H., Thoemmes, F., Renneberg, B., Schultze, J., \& Weiler, M. (2014b). Propensity scores as a basis for equating groups: basic principles and application in clinical treatment outcome research. Journal of Consulting and Clinical Psychology, 82(5), 906-919.

Wiener, R. L., \& Brank, E. M. (2010). Problem solving courts: social science and legal perspectives. New York, NY: Springer.

Wiener, R. L.,Winick, B. J., Georges, L. S., \& Castro, A. (2010). A testable theory of problem solving courts: avoiding past empirical legal failures. International Journal of Law and Psychiatry, 33, 417-427.

Wild, T. C., Newton-Taylor, B., \& Alleto, R. (1998). Perceived coercion among clients entering substance abuse treatment: Structural and psychological determinants. Addictive Behaviors, 23(1), 81-95.

Winick, B. J. (2003). Therapeutic jurisprudence and problem solving courts. Fordham Urban Law Journal, 30, 1055-1090. 
Winick, B. J. (2013). Problem solving courts: therapeutic jurisprudence in practice. In R. L.Wiener \& E. M. Brank (Eds.), Problem solving courts: social science and legal perspectives (pp. 211-236). New York: Springer.

Winick, B. J., \& Wexler, D. B. (2002). Drug treatment court: therapeutic jurisprudence applied. Touro Law Review, 18, 479-486.

Worcel, S. D., Furrer, C. J., Green, B. L., Burrus, S. W. M., \& Finigan, M. W. (2008). Effect of family treatment drug courts on substance abuse and child welfare outcomes. Child Abuse Review, 17, $427-443$.

Young, N. K., Boles, S. M., \& Otero, C. (2007). Parental substance use disorders and child maltreatment: overlap, gaps, and opportunities. Child Maltreatment, 12(2), 137-149.

\section{Author Biographies}

Melanie Fessinger served as a graduate research assistant for the Nebraska Resource Project for Vulnerable Young Children at the University of Nebraska's Center on Children, Families, and the Law. She received her master's degree in Legal Studies at the University of Nebraska-Lincoln. She is pursuing a doctorate in psychology with a dual specialization in psychology and law and basic and applied social psychology at the Graduate Center, City University of New York, and John Jay College of Criminal Justice.

Katherine Hazen is a project evaluator for the Nebraska Resource Project for Vulnerable Young Children and the Children's Justice Clinic at the University of Nebraska's Center on Children, Families, and the Law. Prior to this, Katherine was a graduate research assistant for the Nebraska Resource Project for Vulnerable Young Children and the Nebraska Court Improvement Project at the UNL Center for Children, Families, and the Law. She has also had experience working in diverse areas of the criminal justice system. She received her juris doctorate in May 2018 and is a student in the Law-Psychology Program and Social Cognitive Program at the University of Nebraska-Lincoln, pursing a doctorate of philosophy in social psychology.

Jamie Bahm is a project manager with the Nebraska Resource Project for Vulnerable Young Children at the University of Nebraska's Center on Children, Families, and the Law. She also provides training and consultation for the Children's Justice Clinic at the University of Nebraska College of Law. Prior to her current position, she worked for the Nebraska Department of Health and Human Services as the supervisor for the Family Treatment Drug Court program, as well as specializing in casework with adjudicated youth with high behavioral health needs. Jamie earned her master of science and bachelor of science degrees, both in criminology and criminal justice, from the University of Nebraska.

Jennie Cole-Mossman, LIMHP, is the codirector of the Nebraska Resource Project for Vulnerable Young Children at the University of Nebraska's Center on Children, Families, and the Law. She has been the coordinator of the Nebraska Infant and Toddler Court Improvement Project, which was part of the Through the Eyes of the Child Initiative, where she provided technical assistance and training to overcome system barriers for infants and toddlers in the child welfare system. Prior to that time, she was the Young Child Services Coordinator of Project Safe Start Nebraska, a SAMHSAfunded project that provided technical assistance and child-parent psychotherapy to family drug courts in Omaha and Lincoln. She is a licensed independent mental health practitioner with extensive training and experience in early childhood trauma, child-parent psychotherapy, and parent-child relationship assessments and reflective practice. She is an endorsed child-parent psychotherapy trainer and a FAN Reflective Practice trainer. 
Judge Roger Heideman earned his BA from Benedictine College in Atchison, Kansas, in 1984, and then went on to complete his Jd at the University of Nebraska College of Law in 1992. After serving as partner for the law firm of Morris, Titus \& Heideman, Judge Heideman was appointed to the Separate Juvenile Court bench in 2006 by Governor Heineman. He has served as the lead judge for Lancaster County's Through the Eyes of the Child team from 2007 to 2009. He is currently the lead judge for the Lancaster County Family Treatment Drug Court Track.

Eve Brank, JD, PhD, is the director of the University of Nebraska's Center on Children, Families, and the Law and a professor in the Department of Psychology at the University of Nebraska-Lincoln. Her research focuses on the way in which the law intervenes-and sometimes interferes - in family and individual decision-making. That includes issues about raising children (e.g., parental responsibility laws and blaming parents), adult children caring for aging parents, and constitutionally protected rights within the criminal and juvenile justice systems. 